\title{
STRATEGI DAN MEDIA PENDIDIKAN KARAKTER
}

\author{
Hamdan Husein Batubara
}

\author{
Universitas Islam Kalimantan MAB Banjarmasin
}

E-mail: huseinbatubara@gmail.com

\begin{abstract}
This article aims to explore strategies and media of characters education based on the Quran and Islamic education. The method is a research library which collected data or information from sources. Data analysis techniques used thematic interpretationmethods, by searching and interpreting verses of the Quran and Islamic education ideas. The results of this study indicate that the characters dishonest causes kufr, bypocrisy, complicate sustenance, invites hostility, immoral act and the punishment and curse of Allah Swt and Human. The cause lies is the weakness of faith, encouragement lust, arrogant nature and fear of poverty. The Strategies to prevent lie are: 1) strengthening the faith, 2) providing a good understanding to the child about the lies, 3) set the example, 4) a relationship that is open, and 5) no excessive punishment. Media of character education are: 1) an honesty box, 2) a book of achievements contact, and 3) an bonesty canteen.
\end{abstract}

Keywords: Character, Education, Media, Strategy.

\begin{abstract}
ABSTRAK
Artikel ini bertujuan untuk. menelusuri strategi dan media pendidikan karakter menurut konsep Alquran dan ilmu pendidikan Islam. Penelitian ini adalah penelitian pustaka, yakni mengumpulkan data atau informasi dari berbagai sumber. Teknik analisis data yang digunakan adalah metode tafsir tematik, yaitu dengan menelusuri dan menafsirkan ayat-ayat Alquran dan pemikiran pendidikan Islam yang sesuai.Hasil penelitian ini menunjukean babwa karakter tidak. jujur menyebabkan kekufuran, kemunafikan, menyulitkan rezeki, mengundang permusuban, tindakan tidak bermoral, bukuman dan kutukan Allah dan Manusia. Penyebab kebohongan adalah kelemahan iman, dorongan nafsu, sifat arogan dan takut kemiskinan. Strategi untuk mencegah kebohongan adalab: 1) memperkuat iman, 2) memberikan pemahaman yang baik kepada anak tentang kebohongan, 3) memberi contoh, 4) bubungan yang terbuka, dan 5) tidak memberikan bukuman yang berlebihan. Media pendidikan karakter adalab: 1) kotak kejujuran, 2) buku kontak prestasi, dan 3) kantin kejujuran.
\end{abstract}

Kata Kunci: Karakter, Media, Pendidikan, Strategi.

TARBAWY: Indonesian Journal of Islamic Education - Vol. 4 No. 2 (2017) $\mid \mathbf{1 4 0}$ 


\section{PENDAHULUAN}

Dewasa ini, telah banyak orang yang menutupi keburukannya dengan dusta, dan bahkan perbuatan dusta tersebut mereka anggap sebagai kunci penyelamat dirinya untuk meraih berbagai keuntungan. Misalnya dalam istilah sebagian pedagang terdapat suatu ungkapan rahasia umum yang mengatakan, "kalau tidak berdusta maka tidak akan beruntung." Demikian maraknya perbuatan dusta pada era modern ini tentunya adalah sebagai bukti dari rendahnya budi pekerti masyarakat. Sehingga Din Syamsuddin selaku Ketua Pengurus Pusat Muhammadiyah mengatakan bahwa dalam kehidupan berbangsa dan bernegara pada tahun 2011 ini sungguh penuh dengan dusta, terutama dari para pejabat negara(Syamsuddin, 2011). Bahkan sebagian besar dari faktor-faktor penghambat kemajuan bangsa Indonesia adalah karena kurangnya kejujuran para pemimpinnya. Sebab, perbuatan dusta telah mendorong seseorang untuk berlaku khianat, korupsi, dan tidak profesional dalam menjalankan tugasnya.

Konsep dan model pelaksanaan pendidikan karakter pun menjadi bahan perbincangan yang hangat di kalangan para ahli pendidikan. Mereka mulai menyadari bahwa maraknya para pendusta di Indonesia ini tidak terlepas dari ketidakmampuan (kegagalan) sistem pendidikan bangsa ini dalam menanamkan karakter jujur. Hal tersebut antara lain dikarenakan orientasi penddidikan masih terfokus pada penguasaan ilmu pengetahuan dan masih kurang dari sisi penanaman pendidikan karakter. Hal tersebut antara lain diungkapkan oleh hasil penelitian Syaeful Hidayat (2004) yang menemukan bahwa: dari 32 item materi kurikulum PAI yang harus dikuasai di tingkat SMP ternyata 13 item materi fikih, 6 item berkaitan dengan Alquran dan Hadis, keimanan, tarikh, dan tidak lebih dari 6 item berkaitan dengan karakter (Hidayatullah, 2010).

Padahal, Karakter baik seperti jujur adalah salah satu penentu utama kesuksesan seseorang dan kemajuan suatu negara, dan karakter/buruk seperti dusta adalah kumpulan segala keburukan, dan asal dari segala cela, karena akibatnya yang buruk dan hasil akhirnya yang keji. Oleh karena itu, dunia pendidikan seharusnya dapat menyediakan pengobatan alternatif untuk mencegah anak didik dari perbuatan dusta (Al-Hamad, 2007).

Alquran sebagai sumber inspirasi dan mengandung solusi terbaik bagi berbagai permasalahan umat termasuk masaah karakter manusia tentunya memiliki konsep yang jelas tentang perilaku dusta dan hal-hal yang mempengaruhinya. Karenaitu, penulis tertarik untuk melakukan kajian tafsir tematik tentang makna dusta dalam perspektif Alquran dan kemudian dikaitkan dengan konsep pendidikan Islam sehingga dapat ditemukan suatu desain atau strategi pendidikan yang bisa diterapkan untuk mencegah peserta didik dari perbuatan dusta.

\section{METODE PENELITIAN}

Penelitian ini adalah tergolong kepada jenis penelitian pustaka (library

TARBAWY: Indonesian Journal of Islamic Education - Vol. 4 No. 2 (2017) |141 
research) yang bertujuan mengumpulkan data atau informasi dengan bantuan bermacam-macam material yang terdapat di ruang perpustakaan, seperti jurnal, laporan hasil penelitian, majalah ilmiah, surat kabar, buku yang relevan, hasil-hasil seminar, artikel ilmiah yang belum di publikasikan, data internet yang ada kaitannya dengan judul penelitian ini dengan cara menelaah dan menganalisa sumber-sumber itu, hasilnya dicatat dan dikualifikasikan menurut kerangka yang sudah di tentukan (Sukardi, 2003).

Penelitian ini berkaitan dengan pemahaman ayat-ayat al-Qur'an, secara metodologis penelitian ini dapat dimasukkan dalam kategori penelitian eksploratif (Arikunto, 2006). Artinya penelitian ini adalah untuk mencari makna ayat-ayat al-Qur'an yang secara tematis berkaitan dengan kata kadzbun. Teknik analisis data yang digunakan adalah metode tafsir tematik, yaitu suatu cara menafsirkan al-Qur'an sesuai dengan tema atau topik yang ditetapkan (Zuhri, 2006). Selanjutnya untuk menganalisis pemikiran para tokoh pendidikan Islam tentang strategi pendidikan kejujuran maka digunakan analisis isi (Bungin, 2003).

\section{HASIL PENELITIAN DAN PEMBAHASAN}

\section{Tafsir Ayat-Ayat yang Menjelaskan Perilaku Tidak Jujur}

Adapun ayat-ayat yang berkaitan dengan dusta (tidak jujur) sangat banyak sekali. Kata kunci yang dapat dijadikan kata kunci untuk menelusuri pandangan Alquran tentang perilaku dusta adaah kata kadriba, yang berarti الصِّدْقِ نَقِيْضُ : lawan dari jujur atau menyalahi kebenaran (Mukarram, th).

Hasil perhitungan penulis terhadap kata-kata yang satu akar degan kata kadziba di dalam Alquran كَنَّبَتْ sebanyak 1 kata, كَنَبَنَّ sebanyak 1 kata,

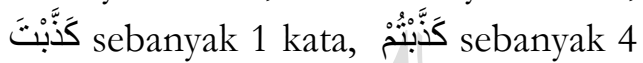

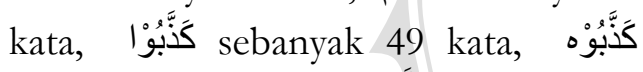

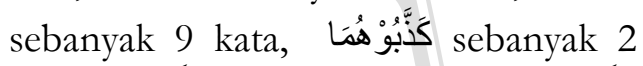

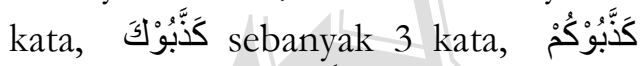
sebanyak 1 kata, كَنَّبُ sebanyak 5 kata, sebanyak 3 kata, الكَّبُوْنَ sebanyak 17 kata, كَاذِبَا sebanyak 15 kata, كَاذَبَّة sebanyak 2 kata, كَذَبُبُ sebanyak 1 kata, كَاذِبْ sebanyak 2 kata, كَاذِبْونْ sebanyak13 kata. Secara umum, kata-kata tersebut bermakna kemunafikan, memanipulasi agama, menuduh orang berzina, mendustakan, dan mengingkari. Semua sifat tersebut adalah lambang kehinaan dan sumber kecelakaan di dunia dan akhirat (Thalib, 2008).

Di antara ayat Alquran yang menjelaskan tentang perilaku tidak jujur adalah surat Al-Isra' [17] ayat 36 yang artinya sebagai berikut: "Dan janganlah kamu mengikuti apa yang kamu tidak mempunyai pengetahuan tentangnya. Sesunggubnya pendengaran, penglibatan dan bati, semuanya itu akan diminta pertanggungan jawabannya". Shihab (2000) menjelaskan bahwa ayat ini bermaksud melarang manusia untuk jangan berucap apa yang tidak engkau ketahui, dan janganlah mengaku tahu apa yang engkau tidak tahu atau mengaku mendengar apa yang engkau

TARBAWY: Indonesian Journal of Islamic Education - Vol. 4 No. 2 (2017) | 142 
tidak dengar. Sesunggubnya pendengaran, penglihatan dan hati, yang merupakan alat-alat pengetahuan akan ditanyai tentang bagaimana pemiliknya menggunakannya atau pemiliknya akan dituntut mempertanggungjawabkan bagaimana ia menggunakannya. Disisi lain, ayat ini juga bermaksud mencegah sekian banyak keburukan, seperti tuduhan, sangka buruk, kebohongan dan kesaksian palsu.

Al-Maraghi (1993) menjelaskan bahwa surat surat Al-Isra' [17] ayat 36 di atas merupakan undang-undang yang mengandung banyak persoalan kehidupan, antara lain para penafsir mengeluarkan beberapa pendapat.

a. Ibnu Abbas mengatakan: "Janganlah kamu menjadi saksi kecuali atas sesuatu yang diketahui oleh kedua matamu, didengar oleh kedua telingamu dan dipahami oleh hatimu".

b. Qatadah mengatakan pula: Janganlah kamu mengatakan "saya telah mendengar", padahal kamu belum pernah mendengar," atau saya telah melihat," padahal kamu tidak pernah melihat, atau "saya mengetahui," padahal kamu belum tahu.

c. Ada pula yang mengatakan bahwa yang dimaksud ayat di atas adalah melarang berkata-kata tanpa ilmu, walaupun hanya persangkaan dan waham belaka, sebagaimana firman Allah Swt. dalam surat Al-Hujurat [49] ayat 12.

d. Adapula yang mengatakan bahwa yang dimaksud adalah melarang orang-orang musyrik dari kepercayaan-kepercayaan mereka yang didasarkan kepada taqlid kepada nenek moyang dan hanya mengikuti hawa nafsu belaka. Hal tersebut ditunjukkan firman Allah Swt. dalam surat An-Najm [53] ayat 23 .

Berdasarkan penjelasan para penafsir tersebut maka dapat diketahui bahwa salah satu contoh perbuatan dusta adalah mengatakan sesuatu yang tidak diketahuinya. Sebab, berkata dengan tanpa pengetahuan sangat dekat sekali dengan perbuatan dusta. M. Quraish Shihab menjelaskan bahwa ada tiga kemungkinan yang dapat dipilih oleh penjawab yang tidak jelas baginya duduk soal dan jawaban yang tepat, yaitu: 1) Berbohong, bila bohongnya dalam bidang agama maka ia akan mendapatkan dosa besar; 2) Menduga-duga. Dengan menduga, jawaban memang boleh jadi secara kebetulan mengena, tetapi Alquran mengingatkan manusia dalam surat $\mathrm{Al}$ Hujurat [49] ayat 12 bahwa sebagian dugaan adalah dosa; 3) Menjawab dengan: "Saya tidak tahu". Jawaban inilah yang sering kali diucapkan sahabat Nabi Saw. dan para ulama, karena mereka berkeyakinan bahwa "yang paling berani berfatwa adalah yang paling berani menghadapi neraka (Shihab, 2000).

Perbuatan dusta tentunya akan berakibat buruk pada korbannya dan khususnya pada dirinya sendiri. Karena itu Allah SWT. telah menetapkan berbagai hukuman bagi para pendusta, yaitu: 1) disiksa dalam api neraka (QS. An-Nahl/16: 62); 2) tidak akan mengalami keberuntungan (QS.An-Nahl [16] ayat 116); 3) mendapat siksa saat menghembuskan nafas terakhir (QS.Al-An'am [6] ayat

TARBAWY: Indonesian Journal of Islamic Education - Vol. 4 No. 2 (2017) | 143 
93); 4) mendapatkan siksaan yang berlipat ganda (QS. Al-A'raf [7] ayat 38).

Perbuatan dusta pada dasarnya tidak tercipta dengan sendirinya, sebab perbuatan dusta berlawanan dengan kesadaran spiritual manusia. Di dalam Alquran Allah menjelaskan bahwa perbuatan dusta itu timbul antara lain ketika hati sudah dirasuki oleh kesombongan (QS. Al-Jatsiyah/ 45: 78). Imam Al-Maraghi menjelaskan bahwa surat Al-Jatsiyah/ 45: 7 menyatakan bahwa orang-orang yang mendustakan ayat-ayat Allah yang telah diturunkan kepada Nabi Muhammad Saw., (yakni Alquran) adalah orang yang bersikap sombong dan dengki atas terpilihnya Nabi Muhammad Saw. sebagai Rasul Allah, dan mereka juga menganggap diri mereka lebih utama daripadanya. Oleh karena itu, mereka akan dimasukkan ke dalam api Neraka. Mereka pun akan kekal disana untuk selama-lamanya (Al-Maraghi, 1993).

Dalam sebuah riwayat dijelaskan bahwa surat Al-Jatsiyah [45] ayat 8 ini turun berkenaan dengan perbuatan Nadhar bin Harits yang menyibukkan kaumnya untuk mendengar ceritacerita dari bangsa non Arab sehingga mereka lalai untuk mendengarkan ayat-ayat Alquran (Az-Zuhaily, t.t.). Al-Mawardi menjelaskan bahwa maksud kata أَفَّاكٍ di dalam ayat ini adalah memiliki tiga makna, yaitu 1) orang yang banyak berdusta, 2) Orang yang mendustakan Allah Swt., dan 3) para peramal (Al-Mawardy, t.t.). Sebagai bentuk pendidikan kepada mereka dapat dilakukan dengan memberikan peringatan kepada mereka tentang bahaya-bahaya dari perbuatan dustanya.

Surat Al-Maidah ayat 41, Allah Swt. menjelaskan siksa yang akan diterima oleh kaum Yahudi akibat dusta yang mereka perbuat adalah kehinaan di dunia dan di akhirat dan mereka akan mendapatkan siksaan yang besar. Menurut Hadis yang diriwayatkan Ahmad, Muslim, dan lainnya dari $\mathrm{Al}$ Bara' bin Azib, dia berkata bahwa surat Al-Ma idah ayat 41 turun berkenaan dengan kisah berikut.

"Suatu saat, orang-orang Yahudi lewat di depan Rasulullah Saw. sambil mengiring seseorang yang mendapat hukuman berzina dengan cara dijemur dan dipukul. Rasulullah Saw. memanggil-manggil orang-orang Yahudi itu sambil mengajukan pertanyaan, "apakah seperti itu kamu mendapati hukuman bagi orang yang berzina di dalam kitab Taurat?" mereka menjawab, "Iya." Beliau bersabda, Demi Allah aku bertanya kepada kalian, apakah demikian kalian dapati hukuman dalam kitab Taurat terhadap orang yang berbuat zina?" Pendeta mereka menjawab; "Demi Allah, tidak demikian."Sekiranya engkau tidak bersumpah lebih dulu dalam bertanya, tentu tidak akan aku jelaskan masalah ini kepadamu. Yang aku dapati dari Taurat, bagi orang yang berbuat zina adalah hukuman rajam. Akan tetapi, karena banyak di antara pemimpin Yahudi melakukan perbuatan zina, maka kami biarkan.Sementara jika yang melakukan adalah orangorang lemah, maka kami menghukum mereka. Oleh karena itu, kami mengadakan musyawarah untuk mengubah hukum itu dengan memberlakukan hukuman ringan 
bagi pezina, baik pembesar maupun orang lemah. Lalu, kami sepakat dengan hukuman dijemur dan dipukuli." Mendengar jawaban ini Rasulullah Saw. bersabda; "Ya Allah sesungguhnya aku adalah orang pertama yang menegakkan sunah-Mu setelah orang-orang Yahudi menghapuskannya." Lalu, Rasulullah Saw. memberlakukan kembali hukuman rajam dan turunlah surat $\mathrm{Al}-\mathrm{Ma}$ idah/5 ayat 41 (Shihab, 2000).

Berdasarkan penjelasan beberapa ayat-ayat di atas, maka secara tegas Allah SWT. Mengharamkan perbuatan dusta. Pelarangan tersebut bertujuan untuk mencegah manusia dari sifat kekufuran (HR. Ahmad: 8276) dan perilaku-perilaku buruk (HR. Muslim: 4721). Secara rinci, Alquran telah menyebutkan beberapa bahaya yang ditimbulkan perbuatan dusta, yaitu

a. Mempersempit jalan rezeki (QS. An-Nahl/16: 62).

b. Membunuh karakter seseorang. (QS. An-Nur/ 24: 7).

c. Menjerumuskan manusia kepada kecelakaan. (QS. Al-Qamar/54: 33.).

d. Menyebabkan kekufuran (QS. AlAnkabut/ 26: 68, An-Nahl/16: 105 dan An Najm/ 53: 11).

e. Mendekatkan seseorang kepada sifat Munafik (QS. At-Taubah/9: 77 dan Az Zumar/ 39: 60).

f. Membuat orang lain teraniaya (QS. Az-Zumar/ 39: 32).

g. Menyesatkan orang yang disekitarnya (QS. Al-An'am/6: 93 dan Az-Zumar/ 39: 32).

h. Melahirkan berbagai perbuatan maksiat yang lain. seperti perbuatan aniaya, diskriminasi, dan semakin sering berdusta untuk menutupi kebohongannya. (QS. Al-Jatsiyah/45: 7).

i. Mendapat laknat dari Allah, Rasulnya, dan seluruh manusia. (QS. An-Nur/ 24: 7).

j. Mendapat siksa yang pedih di akhirat. (QS. An-Nisa'/4: 50).

Penjelasan Alquran dan hadis terhadap berbagai bahaya-bahaya dari perbuatan dusta adalah secara tidak langsung menunjukkan bahwa perbuatan dusta pada dasarnya adalah dibenci oleh naluri setiap manusia . Oleh karena itu pada saat seseorang berdusta maka akan timbul kegelisahan dan keresahan di dalam dirinya. Namun, karena rendahnya kesadaran manusia terhadap bahayabahaya yang ditimbulkan perbuatan dusta tersebut, atau mungkin karena berbagai godaan yang menyertainya membuat pikirannya sempit sehingga ia mengabaikan berbagai bahaya tersebut. Adapun faktor-faktor yang mendorong seseorang untuk berdusta adalah sebagai berikut.

a. Lemahnya Iman. (QS. AnNahl/16: 105).

b. Dorongan Hawa Nafsu. (QS. AlAn'am/6: 150).

c. Takut Hilang Jabatan/ mata pencaharian. (QS. Al-Maaidah/5: 41).

d. Sifat Sombong. (QS. Al-A'raf/7: 36).

e. Untuk menutupi kebohongannya. (QS. Al-Mukminun/ 23: 105).

Dilihat dari objek kata kadriba pada ayat-ayat di atas, dapat diketahui bahwa jenis-jenis perbuatan dusta yang

TARBAWY: Indonesian Journal of Islamic Education - Vol. 4 No. 2 (2017) | 145 
diungkapkan Allah Swt. cukup banyak sekali, antara lain

a. Mendustakan ayat-ayat Allah, mendustakan Rasul Allah, mendustakan ajaran agama, dan mendustakan rezeki yang diberikan Allah. Inilah jenis perbuatan dusta yang paling besar bahayanya dan menyebabkan kekufuran.

b. Memanipulasi kebenaran fakta ataupun menukar informasi yang benar dengan yang salah, menuduh orang dengan sesuatu yang buruk. Inilah jenis perbuatan dusta yang dapat menzhalimi orang lain, dan perbuatan ini juga mengikis keimanan seseorang.

c. Memperindah atau memperburuk suatu fakta yang sebenarnya. Ini lah jenis dusta yang sering disepelekan masyarakat pada umumnya.

Dengan demikian, terjadinya perbuatan dusta antara lain dapat dijadikan indikator dari dari kualitas keimanan seseorang. Artinya ketika kualitas keimanan seseorang turun maka saat itu pula kesadaran spiritualnya tertutup dan ia pun berani melakukan perbuatan dusta.

\section{Strategi Pendidikan Karakter}

Dalam tradisi Islam, pendidikan karakter merujuk pada teori fitrah yang bersumber dari hadits nabi Muhammad SAW. yang berbunyi

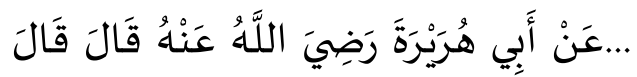

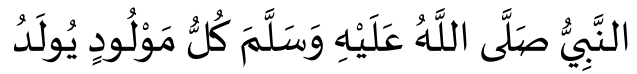

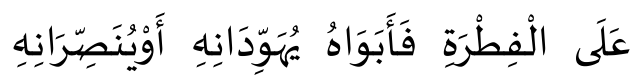

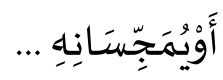

“... Dari Abu Hurairah r.a., berkata; Nabi Saw., bersabda: "Setiap anak dilahirkan dalam keadaan fithrah. Kemudian kedua orang tunyalah yang akan menjadikan anak itu menjadi Yahudi, Nashrani atau Majusi ..." (Bukhari - 1296).

Merujuk pada konsep fitrah di atas, pada dasarnya manusia berpotensi untuk memiliki karakter yang baik. Hanya saja faktor di luar diri anak memiliki peran yang sangat besar dalam membentuk karakter ataupun kepribadian seseorang (Chirzin, 2007). Di sinilah pentingnya peran pendidikan dalam menjaga fitrah manusia agar tetap suci dan teaktualisasi dalam kepribadian yang baik. Pendidikan karakter jujur memerlukan waktu yang panjang dan konsisten agar karakter tersebut tertanam dalam pribadinya. Adapun hal-hal yang perlu dilakukan untuk membangun karakter jujur adalah sebagai berikut.

\section{a. Memperkuat keimanan}

Perilaku dusta menjadi indikator lemahnya iman seseorang (QS. An-Nahl/16: 105). Artinya ketika kualitas keimanan seseorang turun maka saat itu pula kesadaran spiritualnya tertutup dan ia pun berani melakukan perbuatan dusta. Oleh karena itu, pendidikan haruslah menumbuhkan dan menjaga stabilitas keimanan seseorang.

Pendidikan Islam tidak dapat dilepaskan dari nilai-nilai taubid, karena hakikat ilmu adalah bersumber dari Allah SWT. Allah yang mengajari manusia melalui qalam dan 'ilm. Qalam adalah konsep tulis-baca yang memuat simbol penelitian dan eksperimentasi

TARBAWY: Indonesian Journal of Islamic Education - Vol. 4 No. 2 (2017) | 146 
ilmiah. Sedangkan 'ilm adalah alat yang mendukung manusia untuk meningkatkan harkat dan martabat kemanusiaannya. Melalui konsep tarbiyyat, ta'dib, dan ta'lim yang telah dikembangkan oleh para ahli mengacu kepada bagaimana membina umat manusia untuk berhubungan dengan Allah sebagai Dzat Yang Maha Mendidik, sehingga setiap amal perbuatannya tak pernah lepas dari nilai-nilai ketuhanan.

\section{b. Proses pemahaman terhadap kejujuran}

Sangat sulit menanamkan sikap kejujuran kepada peserta didik apabila guru tidak memberikan pemahaman yang memadai tentang makna kejujuran. Selama ini, pendidikan karakter tentang kejujuran hanya sekedar mengajarkan bahwa jujur adalah salah satu ciri orang yang baik, dan sementara berbohong adalah perbuatan yang tidak baik. Di sisi lain, guru kurang memberikan pemahaman kepada peserta didik tentang alasan mengapa ia harus bersikap jujur, apa yang didapatkannya ketika ia bersikap jujur dan berbohong, serta bagaimana contoh-contoh perbuatan dusta dan jujur, sebagaimana dijelaskan oleh Alquran dan Hadis di atas. Karena itu, pembelajaran kejujuran berhenti sebatas pemahaman yang dihafalkan, namun tidak sampai pada tahap pengahayatan dan pengamalan.

\section{c. Keteladanan}

Kata teladan di dalam Alquran diproyeksikan dengan kata uswah yang kemudian dibelakangnya diberi kata sifat hasanah yang berarti baik, sehingga terdapat ungkapan uswah hasanah yang artinya teladan yang baik (Nata, 2005). Keteladanan juga merupakan sebuah sikap dan perilaku yang muncul dari hati nurani yang paling dalam, sehingga apa yang dilakukan tidak menyimpang dari kehendak Tuhan dan norma-norma yang ada ditengah-tengah masyarakat (Qutub, 1998).

Guru sebagai pewaris para Nabi harus mampu menempatkan dirinya sebagai sosok panutan bagi peserta didik, yang segala gerak-gerik dan sikapnya langsung terlihat oleh peserta didik. Oleh karena itu, untuk menumbuhkan sikap jujur pada peserta didik, guru harus memberikan contoh yang kongkret dengan cara berusaha bersikap jujur dan disiplin dalam setiap kesempatan.Selain itu, orang tua juga memegang peranan penting dalam menumbuhkan karakter jujur bagi bagi peserta didik. Oleh sebab itu, sekolah perlu melakukan kerjasama yang intensif dengan keluarga peserta didik agar mereka membantu program pengembangan karakter yang dilaksanakan di sekolah.

\section{d. Pembiasaan}

Ada sebuah ungkapan "Orang biasa karena biasa" atau dalam ungkapan lain: Pertama-tama kita membentuk kebiasaan, kemudian kebiasaan itu akan membentuk kita. Terbentuknya karakter siswa memerlukan proses yang lama dan perlu dilakukan secara kontinu (terus-menerus). Oleh karena itu, seorang guru harus memiliki komitmen dan kesabaran untuk menerapkan pembiasaan itu. Pelaksanaan pendidikan karakter 
tidak cukup dengan hanya diajarkan melalui mata pelajaran di kelas tetapi sekolah juga harus melalui pembiasaan pada berbagai kegiatan siswa.

Menjalin hubungan yang
terbuka
Guru dan orang tua harus
berusaha membangun iklim
keterbukaan dengan anaknya. Jika ada peserta didik yang melakukan pelanggaran, sebaiknya ia ditegur dengan menunjukkan letak kesalahannya. Sedapat mungkin, guru tidak berusaha menutupi kesalahan yang dilakukan oleh peserta didik dengan alasan apa pun. Sebab, hal ini akan menjadikan peserta didik selalu merasa aman saat berbuat kesalahan. Disamping itu, berbagai macam peraturan harus ditetapkan dan disampaikan secara jelas beserta sanksi-sanksinya di berbagai kegiatan dan dicetak dalam bentuk banner.

Perlu disadari bahwa keterbukaan guru atau orang tua terhadap peserta didik akan memperkecil kemungkinan ia bersikap kurang jujur terhadap dirinya sendiri dan orang lain. Sebab, dengan terbangunnya sikap keterbukaan, ia merasa memiliki tempat curahan perhatian dan kasih sayang, yang ditunjukkan dengan adanya sikap keterbukaan itu.Keterbukaan juga dapat dilakukan oleh guru dalam rangka menunjukkan hasil prestasi peserta didik. Guru jangan menutupi fakta yang terjadi jika memang ada peserta didik yang meraih prestasi rendah dalam menempuh pendidikan,demikian pula sebaliknya. Dengan berusaha membangun iklim keterbukaan, peserta didik secara perlahan akan memahami pentingnya bersikap jujur dan terbuka.

\section{f. Tidak bereaksi berlebihan \\ Cara lain untuk mendorong} peserta didik agar bisa bersikap jujur adalah dengan tidak bereaksi berlebihan bila ia berbohong. Guru dan orang tua mesti bersikap atau bereaksi secara wajar ketika mendapati anak didiknya berbuat dusta sekaligus membantunya agar berani mengatakan kebenaran. Sebab, setiap orang sebenarnya sadar bahwa kebohongan yang telah ia lakukan telah membuat guru ataupun orang tuanya kecewa. Namun, jika guru bereaksi berlebihan saat menunjukkan kekecewaan, peserta didik akan merasa ketakutan untuk berkata jujur di depan gurunya.

Ketakutan karena reaksi berlebihan, seperti marah, memberi hukuman yang terlalu berat, ataupun lainnya akan memaksa peserta didik secara perlahan mempelajari kebohongan. Ia akan berusaha mencari cara untuk mengingkari dan tidak berani berkata jujur karena takut akan mendapatkan reaksi serupa. Maka, meskipun guru merasa kecewa atas kebohongan yang dibuat oleh peserta didiknya, sebaiknya guru menunjukkan kekecewaan itu secara wajar.

Selain itu, hendaknya guru memberikan pengertian kepada peserta didik dengan cara yang arif dan bijaksana bahwa kebohongan yang ia buat memang membuat guru kecewa. Namun, sebaiknya guru menjelaskan bahwa guru merasa senang karena ia

TARBAWY: Indonesian Journal of Islamic Education - Vol. 4 No. 2 (2017) | 148 
telah berani mengakui dan mengatakan kejujuran. Dalam hal ini, yang terpenting adalah mendorongnya untuk berani mengatakan kejujuran, dan meninggalkan perbuatan berbohong (Aunillah, 2011).

\section{Media Pendidikan Karakter}

Membentuk karakter jujur pada peserta didik memang tidak bisa dilakukan dengan sekedar menyampaikan materi kepadanya. Pihak sekolah harus menyediakan media ataupun alat bantu yang dapat mendukung terciptanya iklim kejujuran pada dirinya (Hidayatullah, 2010).

\section{a. Kotak kejujuran}

Kotak kejujuran adalah sebuah wadah untuk barang-barang yang ditemukan di sekitar sekolah, mulai dari dasi, kopiah, hingga uang. Peserta didik atau personil sekolah yang menemukan barang berharga di lingkungan sekolah diwajibkan untuk memasukkannya ke dalam kotak itu. Sehingga, jika ada seseorang yang merasa kehilangan, ia bisa langsung melihat ke kotak tersebut, dengan seizin guru yang menjaganya. Kunci dari kotak kejujuran tersebut dapat dipegang oleh salah seorang guru yang diberikan amanat.

\section{b. Buku Kontak Bina Prestasi (KOBINSI)}

Buku Kontak bina Prestasi adalah buku catatan yang disediakan oleh pihak sekolah untuk mengawasi berbagai kegiatan siswa selama berada di luar sekolah.Kemudian buku tersebut secara berkala dilaporkan peserta didik kepada wali kelasnya untuk dievaluasi dan dinilai.

Tujuan dibuatnya buku itu adalah memantau kegiatan keagamaan peserta didik selama ada di rumah, seperti shalat lima waktu dan mengaji Alquran. Buku tersebut berisi catatan tentang kerajinan ibadah peserta didik yang harus ia isi sendiri, sehingga bisa melatih sikap jujur dan kedisiplinannya, bahkan saat di luar sekolah sekalipun.

\section{c. Kantin kejujuran}

Kantin kejujuran adalah kantin sekolah sebagaimana biasanya yang didesain untuk membina karakter jujur siswa. Kantin kejujuran ini dapat dikelola langsung oleh sekelompok siswa ataupun pihak tertentu yang dipercaya sekolah. Ciri khas dari kantin kejujuran ini adalah tidak ada penunggunya. Jadi, kantin tersebut sudah didesain dengan susunan makanan dan minuman yang dilengkapi dengan label harga dan tersedia juga kotak/ kaleng pembayaran yang sudah diisi dengan uang pecahan sehingga setiap pembeli makanan dan minuman dapat melakukan transaksi ataupun pebayaran dengan sendiri dan mengambil pecahan uangnya sendiri. Semua transaksi berjalan tanpa pengawasan, hanya berbekal kejujuran. Warung ini akan melatih kejujuran, sebuah nilai kehidupan yang menjadi cikal bakal hidup terbebas dari korupsi (Aunillah, 2011).

\section{KESIMPULAN}


Berdasarkan kajian tafsir tematik di atas, penulis menyimpulkan bahwa perbuatan dusta itu dapat dicegah dan dibuang dari diri manusia. Pencegahan tersebut dapat dilakukan dengan menciptakan suasana sosial yang baik bagi pertumbuhan akhlaknya untuk merangsang kesadaran moral.

Pendidikan kejujuran ini penting dilakukan sejak dini karena perbuatan dusta dapat mengotori fitrah manusia. Di dalam Alquran, Allah Swt. telah berulang-ulangkali memberikan teguran, larangan, peringatan, dan ancaman kepada manusia untuk menghindari perbuatan dusta. Perbuatan dusta adalah sumber bencana dan dapat merangsang timbulnya berbagai perbuatan maksiat.

Pendidikan kejujuran dapat terealisasi dengan baik, apabila orang tua anak dan seluruh sivitas akademik sekolah dapat bekerjasama secara kompak untuk mendukung pendidikan kejujuran tersebut. Strategi pendidikan yang dapat dilakukan untuk mencegah anak dari perbuatan dusta dapat dilakukan dengan: 1) memperkuat keimanan, 2) memberikan pemahaman yang baik kepada anak perihal dusta, 3) memberikan teladan, 4) menjalin hubungan yang terbuka, dan 5) tidak memberikan hukuman yang berlebihan. Adapun di antara media pendidikan karakter jujur adalah 1) kotak kejujuran, 2) buku kontak bina prestasi, dan 3) kantin kejujuran.

\section{REFERENSI}

Al-Hamad, M. b. (2007). AkblakAkblak Buruk; Fenomena Sebabsebab Terjadinya dan Cara
Pengobatannya. Bogor: Pustaka

Darul Ulum.

Al-Maraghi, A. M. (1993). Tafsir AlMaraghi, Juг XV, Penerjemah: Babrun Abu Bakr, dkek. Semarang: PT. Toha Putera.

Al-Mawardy, A. A.-H. (t.thn.). Annakati wa al-Uyun, Juz 4.

Diambil kembali dari Aplikasi Maktabah Syamilah.

Arikunto, S. (2006). Prosedur Penelitian Suatu Pendekatan Praktik. Jakarta: Rineka Cipta.

Aunillah, N. I. (2011). Panduan Menerapkan Pendidikan Karakter di Sekolah. Jogjakarta: Laksana.

Az-Zuhaily, W. (Tth). At-Tafsir AlWajiz ala Hamisil Quranil Azdim. Syiria: Darul Fikr.

Bungin, B. (2003). Analisis Data Penelitian Kualitatif. Jakarta: PT. Raja Grafindo Persada.

Chirzin, M. (2007). Belajar dari Kisah Kearifan Sababat: Ikbtiar Pengembangan Pendidikan Islam,. Yogyakarta: Pilar Media.

Hidayatullah, F. (2010). Pendidikan Karakter Membangun Peradaban Bangsa. Surakarta: Yuma Pustaka.

Mukarram, I. M.-F.-D. (tth). Lisan alArab, jilid 6. Beirut: Dar al-Ahya.

Nata, A. (2005). Filsafat Pendidikan Islam. Jakarta: Gaya Media Pratama.

Qutub, M. (1998). Sistem Pendidikan Islam. Bandung: al-Ma'Arif.

Shihab, M. Q. (2000). Tafsir al-Misbah; Pesan, Kesan dan Keserasian AlQur'an. Jakarta: Lentera Hati.

Sukardi. (2003). Metodologi Penelitian Pendidikan: Komnpetensi dan

TARBAWY: Indonesian Journal of Islamic Education - Vol. 4 No. 2 (2017) | 150 


\section{Hamdan Husein Batubara}

Praktiknya . Jakarta: PT. Bumi Aksara.

Syamsuddin, D. (2011, Desember 23). 2011 Tahun Penub Dusta. Diambil kembali dari Kompas: http://oase.kompas.com

Thalib, M. (2008). Kamus Kosa Kata Alquran. Yogyakarta: Ma'alimul Ussrah Media \& Pusat Studi Islam Nabawy.

Zuhri, A. (2006). Studi Al-Qur'an dan Tafsir (Sebuab Kerangka Awal). Jakarta: Hijri Pustaka Utama. 